\title{
The Effect of Market Orientation on the Use of Fintech and Utilization of Online-Based Marketing Technology and Its Implications on SME Marketing Performance
}

\author{
Humam Santosa Utomo ${ }^{1}$, Moh. Heru Budihantho ${ }^{2}$ Sari Listyorini ${ }^{3}$ \\ \{humamsantosautomo@upnyk.ac.id ${ }^{1}$, moh.herubudihantho@gmil.com ${ }^{2}$, sarieliest@gmail.com ${ }^{3}$ \} \\ Department of Business Administration, Faculty of Social and Political Sciences, Universitas \\ PembangunanNasional Veteran Yogyakarta- Indonesia ${ }^{1}$, Department of Business \\ Administration, STIA Bina Banua Banjarmasin- Indonesia ${ }^{2}$, Department of Business \\ Administration, Faculty of Social and Political Sciences, Universitas Diponegoro, Semarang- \\ Indonesia ${ }^{3}$
}

\begin{abstract}
Changes in the business environment have encouraged SMEs to take advantage of fintech and marketing technology to improve marketing performance. Consumer behavior has changed in seeking product information and efficient transaction processes. However, not all SMEs have a clear market orientation in responding to a rapidly changing environment. This study aims to examine the effect of market orientation on the use of fintech and the use of online-based marketing technology. The study was conducted on 100 fashionbased Small and Medium Enterprises in Yogyakarta and Semarang which were selected by purposive sampling technique. The analytical tool used is WarpPLS. Thefindings of this study indicate that market orientation has a significant effect on the use offintech and the use of online-based marketing technology. Market orientation has no significant effect on marketing performance. Meanwhile, the use of fintech and the use of online-based marketing technology has a significant effect on marketing performance.
\end{abstract}

Keywords: market orientation; utilization of fintech; use of online-based marketing technology; SME marketing performance

\section{Introduction}

The changing business environment has changed rapidly during the COVID-19 pandemic. During the COVID-19 pandemic, consumer behavior patterns have changed drastically. Indonesian government regulations limit physical contact thereby encouraging the use of online media. Fashion SMEs is one of the companies that have difficulty interacting directly with consumers. This encourages SMEs to utilize technology in their business processes to increase competitiveness [1]. Most SMEs have recently used technology in their business processes, so they need to be studied further. However, market orientation also has a role to play in improving the ability of SMEs to serve customers. However, the ability of SMEs to serve consumers during

the pandemic through technology has not measured its effectiveness in improving 
marketing performance. According to Kim et al., SMEs have many obstacles in the application of technology [2]. Therefore, a study is needed to determine whether the application of technology has implications for marketing performance and the role of market orientation in the use of SME technology.

Studies on the application of technology to SMEs during the pandemic are still very limited. This study aims to examine the effect of market orientation on the use of fintech and the use of online-based marketing technology. This study also examines the effect of market orientation, the use of fintech, and the use of online-based marketing technology on the marketing performance of SMEs. This study extends the Technology Acceptance Model to small businesses facing problems during a pandemic [3]. This study also provides benefits for MSEs in managing their business during the pandemic and post-pandemic through the application of financial technology and online-based marketing technology.

\section{Literature Review}

\subsection{Technology Acceptance Model}

Technology Acceptance Model (TAM) as the development of Theory of Reasoned Action is designed to predict new technologies that will be adopted by a group of people or organizations [3], [4]. TAM aims to provide a model for researchers that can help analyze the causes of technology rejection or acceptance. TAM explains computer usage behavior and matches itwith computer acceptance [3]. TAM has shown success in the adoption of various technologiesfrom software to various menu services. TAM develops over 4 periods, namely the introduction, validation, extension, and elaboration periods. The model was first introduced with twovariables that affect attitudes towards use, namely Perceived Usefulness (PU) and Perceived Ease of Use (PEOU), the variable that later emerged was Attitude Toward Using (ATU) which affected the actual use of the system [5]. The second period shows the reliability, consistencyof the TAM model, it is called the validation period. The next period is an extended period where there is an expansion with individual, organizational, and task characteristics. The fourth period is the elaboration period which is a determinant not found between PEOU and PU. Mckechnie et al. researched in the area of financial services which states that TAM helps gain an understanding of the factors that influence the level of technology use [6]. Fintech services apply a new generation of information technology with technological tools for financial innovation so that TAM can adapt to fintech [7]. TAM provides a significant difference withthe adoption of information technology in traditional ecommerce.

\subsection{Market Orientation}

Market orientation is a company's method to create superior performance and behavior to improve company performance [8]. Market orientation has two perspectives, namely a cultural perspective and a behavioral perspective [9]. Market orientation is the extent to which an organization applies the concept of marketing strategy and tactics [10]. Market orientation is an antecedent of customer value, competitive capacity, and financial performance [11]. The dimensions of market orientation are customer orientation, competitor orientation, and coordination between functions [12]. Kohli and Jaworski identify the market orientation process into three phases: generating information from customers, sharing knowledge within 
the company, addressing current and future customer needs [13]. Narver and Slater divide market orientation into three distinct elements, namely customer orientation, competitor orientation which refers to obtaining information from customers and competitors through market needs, and coordination between functions refers to the company's ability to disseminate information by creating customer value through products and services [11]. The concept of market orientation does not only apply to large companies but is relevant to market-oriented SMEs. SMEs can deal with limited resources and compete with larger competitors [14]. SMEs operate close to customers so that access to information from customers is an advantage for SMEs so that interaction with customers is very important [15], [16]. There is a tendency that the level of competitor orientation is much lower in small firms. With a strong orientation from SMEs, it will encourage the ability to identify opportunities and increase competitive advantage [17].

\subsection{The Use of Fintech}

Fintech is not limited to financial services but can provide financing, create new business models (loans and crowdsourcing) and also provide services and provide products as an alternative to traditional financial institutions [18]. Fintech refers to the use of information technology whichincludes Big Data, cloud computing, and mobile technology that is used to improve service quality and efficient management as well as expand the area of financial services [19]. Fintechprovides an opportunity for its users to get a better experience with the use of technology and can directly increase the competitiveness of the financial sector. With Fintech, customers can use services for online payments, fund transfers, loan applications, purchasing insurance policies, asset management and organizational management, crowdfunding, cryptocurrency, and so on [20]. Applications in Fintech allow lower costs for users because they serve directly with service platforms without intermediaries using smartphones [21]. Fintech also provides higher returns to lenders, lower interest rates for borrowers. The use of Fintech makes it possible to use financial services that are easily accessible from mobile phone devices with minimal interaction with commercial providers without the need to go to a bank or financial institution. Fintech can increase financial satisfaction for its users so that fintech was created to makeit easier to use for its users [18]. According to Davis et al., that consumers believe that using fintech services is easy and does not take much time to learn [3].

\subsection{Utilization of Online-Based Marketing Technology}

Activities in marketing are highly dependent on the implementation of technology platforms that are designed to achieve marketing and commercial goals, which later gave birth to marketing technology. Marketing Technology involves the strategies, solutions, and technologies a company uses to fulfill its marketing and commercial goals. Marketing technology is based on the concept of marketing automation, artificial intelligence, and good marketing strategies. Marketing technology is a mediator between business marketing and the technology companies use as solutions for business growth. Marketing technology details targeting, adapting web content according to user needs and interests, detecting new customers [22].

Several studies have adopted marketing technology in small businesses who represent the issue of the impact of the adoption of marketing technology for small businesses [2], [23], [24]. In this marketing technology, the owner plays an important role in understanding 
technology adoption so that it will produce attitudes that determine strategic responses [25]. Owners need to have a vision of the benefits of adopting technology as an important marketing tool. Martin and Matlay found that small businesses may view websites as important marketing tools because they provide direct access to customers [26]. Regarding the relationship between market orientation and technology adoption, it turns out that small businesses play only a small role [27]. Research conducted by Barnes et al., found that there are barriers to the adoption of marketing technology in small businesses [28]. Small businesses tend to carry out directly rather than having to do formal planning [29].

One of the marketing technologies used in digital marketing. Digital marketing provides solutions for companies to promote and market their products. Digital marketing can create or open new markets that were not previously served so that there is an opportunity to open them with digital marketing. Kim mentions digital marketing dimensions that can help business success, namely transactions, interactive, incentive programs, and site design [30].

\subsection{SME Marketing Performance}

Marketing performance is very important for the overall performance of companies including SMEs [27]. Likewise with Gilmore et al., suggest that by creating networks and relationships with owners, SMEs can overcome resource problems and strengthen their marketing performance [31]. The company will be effective if it can create, deliver and communicatehigher value to the target market so that it has good marketing performance and can monitor competitors and ultimately can make better strategies [32]. Marketing performance is a measurement of the level of business performance including sales turnover, number of buyers, profits, and sales growth [33]. Performance metrics can be categorized into financial and non- financial [23]. In Gama's research marketing performance has five dimensions: marketing culture, marketing capabilities, marketing processes, market, and financial performance [34]. Pelham says three indicators of marketing performance are company effectiveness, sales growth, and relative profit growth [35]. His research also suspects that there is a significant relationship between market orientation and company effectiveness and sales growth which in turn increasesprofit growth.

\subsection{Relationship Between Market Orientation and the Use Of Fintech}

TAM has provided a model to analyze the causes of technology acceptance [36]. Marketoriented companies have customer-oriented characteristics so that SMEs try to meet customer needs and desires through technology [12]. Customers want fast and accurate service in obtaining products. Therefore SMEs try to meet customer expectations by implementing fintech in the sales process. Companies not only address the needs of current customers but also future needs by implementing technology applications that provide many conveniences [37]. Voola et al., examine the effect of market orientation on technology adoption which showsthat market orientation affects technology adoption by moderating technological opportunities [38]. Based on this explanation, the following hypothesis can be formulated:

Hypothesis 1. Market orientation has a significant effect on the use of fintech

\subsection{Relationship Between Market Orientation and the Use of Online-Based Marketing Technology}

Market orientation is the extent to which an organization applies the concept of marketing 
strategy and tactics [10] to increase customer value, competitive capacity, and financial performance [11]. Marketing technology is a strategic tool that is a solutionfor companies in achieving marketing and commercial goals. Thus, market orientation directs companies to use online-based marketing technology. Research conducted by Alford found that the adoption of marketing technology can create a stronger market orientation by following effective principles [39]. Based on this explanation, the following hypothesis can be formulated:

Hypothesis 2. Market orientation has a significant effect on the use of online-based marketing technology.

\subsection{Relationship Between Market Orientation and Marketing Performance}

Maydeu-olivares and Lado revealed that market orientation is a company's method to create superior performance and behavior to improve company performance [8]. Market orientation is anantecedent of customer value, competitive capacity, and financial performance [11]. The company can understand well the needs and desires of customers so that they have superior competitiveness in creating marketing performance. Research conducted by Lekmat et. al., shows that there is a direct and indirect influence between Marketing Orientation and marketing performance [40]. Thus, market orientation is predicted to increase marketing performance.

Hypothesis 3. Market orientation has a significant effect on marketing performance

\subsection{Relationship the Use of Fintech and Marketing Performance}

Fintech is used to improve service quality and efficient management, as well as expanding the area of financial services [19]. Companies can apply fintech so that service to consumers becomes faster and more convenient. High service quality certainly increases customer satisfaction which in turn has implications for marketing performance. Anggrain et al., conducted a study on the influence of fintech on marketing performance which showed that fintech had a positive and significant influence on marketing performance [41]. Thus, the use of fintech improves marketing performance.

Hypothesis 4 . The use of fintech has a significant effect on marketing performance.

\subsection{The use of online-based marketing technology and marketing performance.}

Marketing Technology deals with the strategies, solutions, and technologies that companies use to fulfill marketing and commercial goals. Marketing technology is intended to make it easier for companies to communicate with customers, explore important information, and implementmarketing strategies. Online-based technology helps companies in business growth. Marketingtechnology details targeting, adapting web content according to user needs and interests, detecting new customers [22]. Research by Sheikh et al., shows the findings that e- marketing affects performance [42]. Digital marketing helps marketing success through interactivecommunication, incentive programs, site design, and cost efficiency [30]. Hypothesis 5. The use of online-based marketing technology has a significant effect on marketing performance

\section{Method}

This type of research is explanatory research which aims to test and analyze the influence 
between variables. The research was conducted on SMEs engaged in the fashion sector located in the provinces of Yogyakarta and Semarang, Indonesia. The number of respondents is 100 SMEs selected by purposive sampling technique. The respondent's requirements are to have run a fashion business for at least 2 years and do sales both conventionally and online. Market orientation variable is measured referring to Narver and Slater [11]. The use of fintech indicators according to Ryu [20]. Measurement of online-based marketing technology according to research by Kim [30]. Marketing performance is measured according to research by Pelham [35]. The research instrument used was a questionnaire with a 5-point Likert scale for market orientation, use of online-based marketing technology, and marketing performance. Meanwhile, the measurement of the use of fintech variable uses a dummy (yes/no). Researchers tested the quality of the research instrument using validity and reliability tests by distributing to 30 respondents. Testing the validity and reliability using SPSS tools. After the instrument was proven valid and reliable, the researcher distributed questionnaires to 100 respondents who met the criteria. Respondents filled out the questionnaire online and then the data was processed using WarpPLS [43].

\section{Result and Discussion}

\subsection{Result}

Table 1 shows the results of testing the validity and reliability of the research instrument. The test results show that all indicators can be declared valid $(>0.3)$. The results of the reliability test also showed that the instrument used was reliable $(>0.6)$. Therefore, the research questionnaire is appropriate to be used as a data collection instrument.

Table 1. Validity and Reliability Test Results

\begin{tabular}{|c|c|c|c|}
\hline Variable & Indicator & CorrelationCoefficient & Alpha Cronbach \\
\hline \multirow{3}{*}{ Market orientation } & Customer orientation & 0.544 & 0.886 \\
\hline & Competitor orientation & 0.683 & \\
\hline & Inter-functionalcoordination & 0.652 & \\
\hline \multirow[t]{3}{*}{ Use of fintech } & Transfer of funds & 0.767 & 0.784 \\
\hline & Loan application & 0.435 & \\
\hline & $\begin{array}{l}\text { Asset management andfinancial } \\
\text { management }\end{array}$ & 0.629 & \\
\hline \multirow{4}{*}{$\begin{array}{l}\text { Use of online-based } \\
\text { marketing technology }\end{array}$} & Online sales transactions & 0.577 & 0.772 \\
\hline & Incentive program & 0.792 & \\
\hline & Site design & 0.629 & \\
\hline & Interactive technology & 0.779 & \\
\hline \multirow{3}{*}{$\begin{array}{l}\text { Marketing } \\
\text { performance }\end{array}$} & Relative service quality & 0.591 & 0.889 \\
\hline & New product success & 0.792 & \\
\hline & Customer retention & 0.715 & \\
\hline
\end{tabular}

Table 2. Profile of Respondents

\begin{tabular}{ccc}
\hline Gender & Male & $22 \%$ \\
& Female & $78 \%$ \\
Age & $<25$ years & $26 \%$ \\
& $26-35$ years & $35 \%$ \\
& $36-45$ years & $19 \%$ \\
& $46-55$ years & $15 \%$ \\
\hline
\end{tabular}




\begin{tabular}{ccc}
\hline \multirow{3}{*}{ Firm age } & $>55$ years & $5 \%$ \\
& $2-5$ years & $23 \%$ \\
& $6-10$ years & $22 \%$ \\
& $11-20$ years & $44 \%$ \\
& $21-30$ years & $6 \%$ \\
Marital Status & $>30$ years & $5 \%$ \\
& Single & $8 \%$ \\
& Married & $92 \%$ \\
\hline
\end{tabular}

Table 2 shows that most of these respondents are female (78\%) and a small proportion of respondents are male (22\%). The age group of 26-35 years dominated the respondents (35\%) compared to other age groups. The largest company age group is $11-20$ years old (44\%), while the least company age group is $>30$ years old group. Most of the respondents were married $(92 \%)$. The research data was processed using WarpPLS. Based on the results of data processing, it canbe seen that all fit indicators for WarpPLS have met the requirements.

Table 3. Hypothesis test

\begin{tabular}{clccc}
\hline Hypothesis & \multicolumn{1}{c}{ Path } & Coefficient & p-value & HypothesisDecision \\
\hline 1 & Market Orientation Use offintech & 0.765 & 0.000 & Accepted \\
2 & $\begin{array}{l}\text { Market Orientation Use of } \\
\text { online-based marketingtechnology }\end{array}$ & 0.668 & 0.000 & Accepted \\
3 & $\begin{array}{l}\text { Market Orientation } \\
\text { Marketing Performance }\end{array}$ & 0.076 & 0.144 & Rejected \\
4 & $\begin{array}{l}\text { Use of fintech MarketingPerformance } \\
5\end{array}$ & 0.454 & 0.000 & Accepted \\
& $\begin{array}{l}\text { Use of online-based marketingtechnology } \\
\text { Marketing }\end{array}$ & 0.864 & 0.000 & Accepted \\
& Performance & & \\
\hline
\end{tabular}

Table 3 and Figure 1 show the results of hypothesis testing for each influence between variables. Based on the results of data processing, it is known that market orientation has a significant effect on the use of fintech $(p$-value $<0.05)$ so that hypothesis 1 is accepted. Market orientation has a significant effect on the use of online-based marketing technology ( $p$-value $<0.05$ ) so that hypothesis 2 is accepted. Market orientation has no significant effect on marketing performance ( $\mathrm{p}$-value $>0.05$ ) so hypothesis 3 is rejected. Use of fintech has a significant effect on marketingperformance $(p$-value $<0.05)$ so that hypothesis 4 is accepted. The use of online-based marketing technology has a significant effect on marketing performance (pvalue $<0.05$ ) so that hypothesis 5 is accepted.

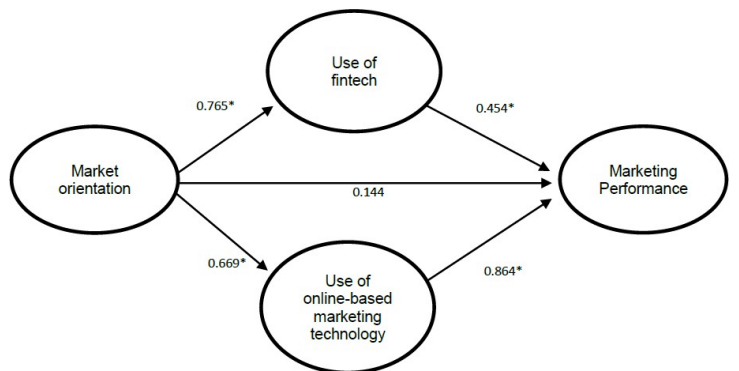

Fig. 1. Tested Hypothesis Model

*Significant at 0.000 level 


\subsection{Discussion}

This study yielded five important findings. First, market orientation has a significant effect on the use of fintech. This finding supports Kohli and Jaworski that companies are trying to meet evolving customer needs. Current and future customers expect convenience in financial services through fintech [44]. Especially during the COVID-19 pandemic, customers limit themselves to interacting with other people or the bank so that SMEs implement online-based financial services.

Second, market orientation has a significant effect on the use of online-based marketing technology. This finding is consistent with Jaworski \& Kohli and Narver \& Slater that market orientation directs companies to implement marketing strategies and tactics to increase customer value [10], [11]. SMEs apply marketing technology to achieve marketing and commercial goals. Customers today want information and services that are fast and accurate based online so that SMEs try to accommodate customer desires. Thus, the stronger the market orientation, the more consistent the company is in implementing online-based marketing technology.

Third, market orientation has no significant effect on marketing performance. These results donot support the opinion of Maydeu-olivares and Lado which states that market orientation creates superior performance and behavior to improve company performance [8]. This result is also inconsistent with Narver \& Slater that market orientation is an antecedent of customer value, competitive capacity, and financial performance [11]. Based on the first and second findings, this third finding can be understood that market orientation does not necessarily affect marketing performance, but there needs to be an implementation of technology developed to meetcustomer expectations.

Fourth, the use of fintech has a significant effect on marketing performance. These results are consistent with the opinion of $\mathrm{Hu}$ et al., that fintech can improve service quality and efficient management, as well as expand the area of financial services [19]. Customers can access payments through technology applications to improve the performance of SMEs as indicated by better service quality, successful new products in the market, and high customer retention. Fifth, the use of online-based marketing technology has a significant effect on marketing performance. These results support Kim that digital marketing helps marketing success through interactive communication, incentive programs, site design, and cost-efficiency [30]. The application of online-based marketing technology has a positive impact on marketing performance as indicated by better service, successful new products in the market, and high customer retention.

The findings of this study have both theoretical and managerial implications. Based on TAM, companies have several reasons for implementing the technology [36]. These results indicate that technology adoption is influenced by how much company orientation to their market. The company's desire to serve customers is the trigger for the use of technology. During the COVID-19 pandemic, customers increasingly need online services, so companies are trying to meet customer expectations by developing financial technology and online-based marketing technology. These findings also have managerial implications. The results show that financial technology and marketing technology are proven to affect marketing performance. Therefore, the application of these technologies becomes important for companies, especially during a pandemic. The technology developed must be oriented to customer needs so that it is in line with customer expectations. 


\section{Conclusion}

The results of this study indicate the importance of the use of fintech and the use of onlinebased marketing technology in influencing the marketing performance of fashion companies. The use of fintech and use of online-based marketing technology is influenced by the company's marketorientation. Thus, market orientation has an important role in directing the behavior of using technology in finance and marketing which has implications for marketing performance. Nevertheless, these results indicate that market orientation has no significant effect on marketing performance. This study has limitations on measuring marketing performance because performance measurement is not comprehensive. After all, not all SMEs have completesales books. Further research can fully accommodate all performance indicators.

\section{References}

[1] M. O'Dwyer dan A. Gilmore, "Competitor Orientation in Successful SMEs: an Exploration of the Impact on Innovation," J. Strateg. Mark., vol. 27, no. 1, hlm. 1-17, 2019.

[2] H. D. Kim, I. Lee, dan C. K. Lee, "Building Web 2.0 Enterprises: A Study of Small and Medium Enterprises in the United States," Int. Small Bus. J. Res. Entrep., vol. 31, no. 2, hlm. 156-174, 2011, doi: https://doi.org/10.1177\%2F0266242611409785.

[3] F. D. Davis, R. P. Bagozzi, dan P. R. Warshaw, "User Acceptance of Computer Technology: A Comparison of Two Theoretical Models," Manage. Sci., vol. 35, no. 8, hlm. 982-1003, 1989, doi: 10.1287/mnsc.35.8.982.

[4] M. Fishbein dan I. Ajzen, Belief, attitude, intention and behaviour: An introduction to theory and research, vol. 27. Massachusets: Reading, 1975.

[5] Y. Lee, K. A. Kozar, dan K. R. T. Larsen, "The Technology Acceptance Model: Past, Present, and Future,” Commun. Assoc. Inf. Syst., vol. 12, no. 50, hlm. 752-780, 2003.

[6] S. McKechnie, H. Winklhofer, dan C. Ennew, "Applying the technology acceptance model to the online retailing of financial services," Int. J. Retail Distrib. Manag., vol. 34, no. 4/5, hlm. 388-410, Jan 2006, doi: 10.1108/09590550610660297.

[7] T. Zhang, C. Lu, dan M. Kizildag, "Banking 'on-the-go': examining consumers' adoption of mobile banking services,” Int. J. Qual. Serv. Sci., vol. 10, no. 3, hlm. 279295, Jan 2018, doi: 10.1108/IJQSS-07-2017-0067.

[8] A. Maydeu-Olivares dan N. Lado, "Market orientation and business economic performance,” Int. J. Serv. Ind. Manag., vol. 14, no. 3, hlm. 284-309, Jan 2003, doi: 10.1108/09564230310478837.

[9] J. M. Armario, D. M. Ruiz, dan E. M. Armario, "Market Orientation and Internationalization in Small and Medium-Sized Enterprises," J. Small Bus. Manag., vol. 46, no. 4, hlm. 485-511, 2008, doi: https://doi.org/10.1111/j.1540627X.2008.00253.x.

[10] B. J. Jaworski dan A. K. Kohli, "Market orientation: Review, refinement, and roadmap," J. Mark. Manag., vol. 1, no. 2, hlm. 119-135, 1996, doi: 10.1007/BF00128686.

[11] J. C. Narver dan S. F. Slater, "The effect of a market orientation on business profitability," J. Mark., vol. 54, no. 4, hlm. 20-35, 1990.

[12] J. Tham, M. S. A. Yazid, A. A. Khatibi, dan S. M. F. Azam, "Internet and Data Security - Understanding Customer Perception on Trusting Virtual Banking Security in 
Malaysia,” Eur. J. Soc. Sci. Stud., vol. 2, no. 7, 2017.

[13] A. K. Kohli dan B. J. Jaworski, "Marketing Orientation: The Construct, Research Propositions, And Managerial Implications," J. Mark., vol. 54, 1990.

[14] Ó. González-benito, J. González-Benito, dan P. A. Muñoz-gallego, "On the Consequences of Market Orientation across Varied Environmental Dynamism and Competitive Intensity Levels," J. Small Bus. Manag., vol. 52, no. 1, hlm. 1-21, Jan 2014, doi: 10.1111/jsbm.12028.

[15] N. A. Morgan, D. W. Vorhies, dan C. H. Mason, "Market Orientation, Marketing Capabilities, and Firm Performance,” Strateg. Manag. J., vol. 30, no. 8, hlm. 909-920, 2009, doi: https://doi.org/10.1002/smj.764.

[16] T. Tammi, H. Reijonen, dan J. Saastamoinen, "Are Entrepreneurial and Market Orientations of Small and Medium-sized Enterprises Associated with Targeting Different Tiers of Public Procurement?," Environ. Plan. C Polit. Sp., vol. 35, no. 3, hlm. 457-475, 2016, doi: https://doi.org/10.1177\%2F0263774X16666814.

[17] M. O'dwyer dan A. Ledwith, "Size matters: Market orientation and NPD in small and large firms," Int. J. Prod. Dev., vol. 12, no. 2, hlm. 107-125, Agu 2010, doi: 10.1504/IJPD.2010.034991.

[18] ING Economics Department, "FinTech for Micro, Small and, Medium Sized Enterprises." ING Economics Department, 2016.

[19] Z. Hu, S. Ding, S. Li, L. Chen, dan S. Yang, "Adoption Intention of Fintech Services for Bank Users: An Empirical Examination with an Extended Technology Acceptance Model," Symmetry, vol. 11, no. 3. 2019, doi: 10.3390/sym11030340.

[20] H.-S. Ryu, "What makes users willing or hesitant to use Fintech?: the moderating effect of user type," Ind. Manag. Data Syst., vol. 118, no. 3, hlm. 541-569, Jan 2018, doi: 10.1108/IMDS-07-2017-0325.

[21] A. Mackenzie, "The Fintech Revolution," London Bus. Sch. Rev., vol. 26, no. 3, hlm. 50-53, 2015, doi: https://doi.org/10.1111/2057-1615.12059.

[22] L. P. Baltes, "Marketing Technology (Martech) -- The Most Important Dimension of Online Marketing," Bull. Transilv. Univ. Brasov, vol. 10, no. 2, hlm. 43-48, 2017.

[23] M. Bulearca dan S. Bulearca, "Twitter: a Viable Marketing Tool for SMEs?," Glob. Bus. Manag. Res. An Int. J., vol. 2, no. 4, hlm. 296-309, 2010.

[24] M. Durkin, P. McGowan, dan N. McKeown, "Exploring social media adoption in small to medium-sized enterprises in Ireland," J. Small Bus. Enterp. Dev., vol. 20, no. 4, hlm. 716-734, Jan 2013, doi: 10.1108/JSBED-08-2012-0094.

[25] G. Simmons, G. A. Armstrong, dan M. G. Durkin, "A Conceptualization of the Determinants of Small Business Website Adoption: Setting the Research Agenda," Int. Small Bus. J. Res. Entrep., vol. 26, no. 3, hlm. 351-389, 2008.

[26] L. M. Martin dan H. Matlay, "Innovative use of the Internet in established small firms: the impact of knowledge management and organisational learning in accessing new opportunities," Qual. Mark. Res. An Int. J., vol. 6, no. 1, hlm. 18-26, Jan 2003, doi: $10.1108 / 13522750310457348$.

[27] A. Kara, J. Spillan, dan O. Deshields, "The Effect of a Market Orientation on Business Performance: A Study of Small-Sized Service Retailers Using MARKOR Scale," $J$. Small Bus. Manag., vol. 43, no. 2, Apr 2005, doi: 10.1111/j.1540-627x.2005.00128.x.

[28] D. Barnes, F. Clear, R. Dyerson, G. Harindranath, L. Harris, dan A. Rae, "Web 2.0 and micro-businesses: an exploratory investigation,” J. Small Bus. Enterp. Dev., vol. 19, no. 4, hlm. 687-711, Jan 2012, doi: 10.1108/14626001211277479.

[29] C. Jones, R. Hecker, dan P. Holland, "Small firm Internet adoption: opportunities 
forgone, a journey not begun," J. Small Bus. Enterp. Dev., vol. 10, no. 3, hlm. 287-297, Jan 2003, doi: 10.1108/14626000310489763.

[30] E. Young Kim dan Y. Kim, "Predicting online purchase intentions for clothing products," Eur. J. Mark., vol. 38, no. 7, hlm. 883-897, Jan 2004, doi: 10.1108/03090560410539302.

[31] A. Gilmore, D. Carson, dan S. Rocks, "Networking in SMEs: Evaluating its contribution to marketing activity," Int. Bus. Rev., vol. 15, no. 3, hlm. 278-293, Jun 2006, doi: 10.1016/j.ibusrev.2006.02.003.

[32] P. Kotler dan K. L. Keller, Manajemen Pemasaran. Jakarta: PT Indeks, 2016.

[33] G. B. Voss dan Z. G. Voss, "Strategic Orientation and Firm Performance in an Artistic Environment," J. Mark., vol. 64, no. 1, hlm. 67-83, 2000.

[34] A. Pimenta da Gama, "An expanded model of marketing performance," Mark. Intell. Plan., vol. 29, no. 7, hlm. 643-661, Jan 2011, doi: 10.1108/02634501111178677.

[35] A. Pelham, "Mediating Influences on the Relationsmp between Market Orientation and Profitability in Small Industrial Firms," J. Mark. Theory Pract., vol. 5, hlm. 1-23, Jul 1997, doi: 10.1080/10696679.1997.11501771.

[36] F. D. Davis, "Perceived Usefulness, Perceived Ease of Use, and User Acceptance of Information Technology," MIS Q., vol. 13, no. 3, hlm. 319-340, 1989, [Daring]. Tersedia pada: https://www.jstor.org/stable/249008?seq=1.

[37] A. K. Kohli dan B. J. Jaworski, "Market Orientation: The Construct, Research Propositions, and Managerial Implications,” J. Mark., vol. 54, no. 2, hlm. 1-18, 1990, doi: https://doi.org/10.2307/1251866.

[38] R. Voola, G. Casimir, J. Carlson, dan M. Agnihotri, "The Effects of Market Orientation, Technological Opportunism, and E-Business Adoption on Performance: A Moderated Mediation Analysis," Australas. Mark. J., vol. 20, no. 2, Mei 2012, doi: 10.1016/j.ausmj.2011.10.001.

[39] P. Alford, "Marketing technology for adoption by small business," Serv. Ind. J., vol. 35, no. 11-12, Jul 2015, doi: 10.1080/02642069.2015.1062884.

[40] L. Lekmat, C. Selvarajah, dan C. Hewege, "Relationship between Market Orientation, Entrepreneurial Orientation, and Firm Performance in Thai SMEs: The Mediating Role of Marketing Capabilities,” Int. J. Bus. Econ., vol. 17, no. 3, hlm. 213-237, 2018.

[41] A. Anggraini, R. Iskandar, dan M. Azis, "The Effect of Financial Performance and Technology Aspects of Market Performances on Banking In Indonesia," Samarinda, 2020.

[42] A. Sheikh, A. Shahzad, dan A. Ku Ishak, "The Growth of E-Marketing in Business-toBusiness Industry and its effect on the Performance of Businesses in Pakistan: Marketing Success,” Int. Multidiscip. J. Soc. Sci., vol. 6, hlm. 178, Jul 2017, doi: 10.17583/rimcis.2017.2704.

[43] N. Kock, WarpPLS 5.0 User Manual. Texas: ScriptWarp Systems, 2015.

[44] A. K. Kohli dan B. J. Jaworski, "Market Orientation :The Construct, Research Propositions, and Managerial Implications," J. Mark., vol. 54, hlm. 1-18, 1990. 